\title{
LOW IRON STATUS: A POSSIBLE RISK FACTOR FOR FEBRILE SEIZURES
}

\author{
M. Senthil Kumar', B. R. Sasikumar² \\ ${ }^{1}$ Associate Professor, Department of Paediatrics, Coimbatore Medical College \& Hospital, Coimbatore, Tamilnadu. \\ ${ }^{2}$ Assistant Professor, Department of Paediatrics, Coimbatore Medical College \& Hospital, Coimbatore, Tamilnadu.
}

ABSTRACT: Low iron status: A possible risk factor for febrile seizures.

INTRODUCTION: Febrile seizures are the most prevalent form of seizures in children between 6 months and 5 years. Though the cause is multi-factorial, there are conflicting reports between studies on iron deficiency and occurrence of febrile seizures. We hereby studied the effect of iron deficiency as a possible cause for febrile seizures.

AIM OF STUDY: To find the association between iron deficiency and febrile seizures in children.

STUDY DESIGN: Case Control Study.

MATERIALS \& METHODS: Study includes 63 children with febrile seizures with age and sex matched 63 children without febrile seizures during a period of one year. Serum ferritin (Single most sensitive test for evaluating the iron status), Hemoglobin, Mean corpuscular volume and Mean corpuscular hemoglobin were measured in all cases and compared with that of controls.

RESULTS: Mean serum ferritin level $(14.5+/-10.6 \mathrm{ng} / \mathrm{ml})$ was significantly lower in febrile seizure group than control group (34.9+/$23.3 \mathrm{ng} / \mathrm{ml})(\mathrm{P} 0.00)$. Proportion of cases with low serum ferritin $(<10 \mathrm{ng} / \mathrm{ml})$ were significantly higher $(65.1 \%)$ than controls (23.8\%) (P0.00).

CONCLUSION: Serum ferritin was significantly lower in children with febrile seizures than control group suggesting that iron deficient children were more prone to febrile seizures.

KEYWORDS: Febrile Seizures, Serum Ferritin, Children, Risk.

HOW TO CITE THIS ARTICLE: M. Senthil Kumar, B. R. Sasikumar. "Low Iron Status: A Possible Risk Factor for Febrile Seizures". Journal of Evolution of Medical and Dental Sciences 2015; Vol. 4, Issue 90, November 09; Page: 15546-15548,

DOI: $10.14260 /$ jemds $/ 2015 / 2228$.

INTRODUCTION: Febrile seizures are the most common type of seizures in children, occurring in $2-5 \%$ of children.(1) Iron deficiency is the commonest micronutrient deficiency worldwide and it is a preventable and treatable condition.(2) There are flurry of studies relating iron deficiency in variety of neurological problems. Monoamine oxidase, an irondependent enzyme has a crucial role in neurochemical reactions in the Central Nervous System.(3,4) Iron deficiency alters the electron transport and neurotransmitter synthesis in the brain thereby altering the normal functioning of the neural tissue.(5) Thus iron deficiency may alter the seizure threshold of a child.(6,7) Iron deficiency is postulated as a risk factor for febrile seizures and it is an easily correctable condition. $(8,9)$ We therefore studied the association between iron deficiency and febrile seizures in children.

MATERIALS AND METHODS: A case control study was conducted in the Department of Pediatrics, Coimbatore Medical College Hospital, Coimbatore, Tamil Nadu, India between March 2014 and February 2015. All children between ages of 6 months and 5 years getting admitted in the pediatric department satisfying the criteria for simple febrile seizures were included in the study.

Financial or Other, Competing Interest: None.

Submission 19-10-2015, Peer Review 20-10-2015,

Acceptance 27-10-2015, Published 07-11-2015.

Corresponding Author:

Dr. M. Senthil Kumar,

B5-21 TVH Ekanta, GV Residency,

Uppilipalayam Post, Coimbatore-641015, Tamilnadu.

E-mail: brucemsenthil@rediffmail.com

DOI:10.14260/jemds/2015/2228.
Children with hematological disorders, chronic illness, neurological deficit, on iron supplementation were excluded. Age, sex and nutritional status matched children hospitalized for febrile illness without seizures were selected as control group.

Sample Size: From a pilot study, the standard deviation of ferritin was found to be 20 . In order to detect a difference of 10 with $5 \%$ level of significance and $80 \%$ power, the sample size needed was 63 in each group.

After getting informed consent from the parents of cases and controls they are subjected to detailed history and clinical examination. Blood samples were collected for measures of serum ferritin - the single most sensitive tool for evaluating the iron status.(10)

Hemoglobin (Hb), Mean Corpuscular Volume (MCV) and Mean Corpuscular Hemoglobin (MCH). Chemiluminescence immunoassay was used for quantitative determination of serum ferritin. Measurement of $\mathrm{Hb}, \mathrm{MCV}$ and MCH were done by using auto-analyzer (Coutler counter). Cases and controls were compared with regards to serum ferritin, $\mathrm{Hb}, \mathrm{MCV}$ and $\mathrm{MCH}$.

Statistical Analysis: The effect of iron status on febrile seizures with odds ratio (OR) and 95\% confidence limit was arrived by univariant analysis. An odds ratio was considered statistically valid and meaningful if the upper and lower limits of confidence interval do not include unity. The value of OR was considered significant if the probability (P) was $<0.05$. All continuous data was analyzed by the use of t-test or Mann Whitney U test. All proportionate data was analyzed with chi-square or Fischer exact test. 
RESULTS: 63 cases and 63 controls were studied. Maximum incidence of febrile seizures was found in the age group of 12 years (58.7\%), the mean age being 18 months. The incidence of febrile seizures was found to be higher in males with a male: female ratio of $1.4: 1.18$ children $(28.5 \%)$ in the febrile seizure group have positive family history and none in the control group.

DISCUSSION: Iron deficiency was found as a significant risk factor for febrile seizures in our study. This is similar to previous studies by Doud As et al. Naveedur Rehman et al. and Alfredo Pisacane et al.(11,12,13) In the study done by Daoud As et al.(11) the mean serum ferritin level was $29.5 \mathrm{ng} / \mathrm{ml}$ whereas in our study it is $14.5 \mathrm{ng} / \mathrm{ml}$. It is probably due to the fact that iron deficiency anemia is more prevalent in our country; the mean serum ferritin level of Indian children was also low.

Doud As et al.(11) in his study found that a significant proportion of children with febrile seizures had only low serum ferritin whereas our study demonstrates a statistically significant difference not only in serum ferritin but also in low Hemoglobin and low Mean Corpuscular Volume. This is similar to the findings by Naveedur Rehman et al.(12) in his study at Karachi. This is probably due to the fact that iron deficiency occurs in three stages. ${ }^{(14)}$

First Stage: Decreased storage of iron.

Intermediate Stage: 'latent iron deficiency' i.e. iron stores are exhausted but anemia has not occurred yet.

The Third Stage: 'Overt iron deficiency' where there is a decrease in the concentration of hemoglobin.

The children in western countries if they are iron deficient are mostly in the early stage, whereas the Indian children and children of our neighboring country Pakistan are in the stages of latent or overt iron deficiency.

We report iron deficiency as a possible and modifiable risk factor for febrile seizures. Developmental problems, risk of pediatric stroke, breath holding spells and febrile seizures are perhaps the tip of the iceberg of the neurological consequences of iron deficiency. With appropriate recognition, treatment or better yet prevention the neurological sequalae of iron deficiency are entirely preventable and perhaps reversible.
CONCLUSION: Serum ferritin is significantly lower in children with febrile seizures as compared to children without febrile seizures.

A follow-up study of children found to be iron deficient at the time of febrile seizures to determine the incidence of subsequent febrile seizures after treatment for iron deficiency would be of great interest.

\section{BIBLIOGRAPHY:}

1. Johnston MV. Seizures in childhood: Kliegman RM, Behrman RE, Jenson HB, Stanton BP. Nelson Textbook of Pediatrics, $20^{\text {th }}$ edition Philadelphia; Saunder Elserver 2015 p. 2829.

2. WHO Iron deficiency anemia. Assessment, Prevention and Control. A guide for program managers WHO/NHD/013 Geneva: 200.

3. Frantzen E, Lennox-Buchtal M, Nygaard A, et al. A genetic study of febrile convulsions. Neurology 1970; 20:909-17.

4. AAP Grand Rounds, iron insufficiency a risk factor for febrile seizures 2002, 8(6); 62-63.

5. Febrile convulsions review and update-J pediatr neurol 2002; 2(1); 22-24.

6. Beard JL. Iron deficiency alters brain development and functioning. J. Nutr 2003; 133: 1468-72.

7. Jyoti B., Seth PK. Effect of iron deficiency on developing rat brain. Indian J. Clin. Biochem. 2002 17: 108-14.

8. Vife WM., Kiser Wr. Iron deficiency anemia and febrile convulsions BMJ. 1996, 313: 1205.

9. Ansun N., Shasi S. Susceptibility to febrile seizures: More than just a faulty thermostat. Canadian J. Neuroscience. 2009; 36: 277-9.

10. Park K., Diagnosis of anemia. In: Park Textbook of Preventive and Social Medicine, 17th edition, Park, Jabalpur, Banarsidas Bhanut; 2002 Nov., pp.424.

11. Daoud AS, Batchia A, Abu Esctarsh F et al. Iron status: A possible risk factor for first febrileSeizures. Epilepsia 2002; 43:740-43.

12. Rehman N, Billoo Ag. Et al. Association between iron deficiency and febrile seizures. J. coll.Physicians surg. Pak.2005; 15(6): 338-40.

13. Pisacane A, Jansone $\mathrm{P}$, Impaliazzo $\mathrm{N}$ et al. Iron deficiency anemia and febrile convulsion. Case Control study in children under 2 years. Brit Med J. 1996; 313-43.

14. Kobrinsky NL, jager JY, Cheang MS, Yats coffRW: Does iron deficiency rise the seizure threshold. ChildNeurol. 1995 10(2); 105-09.

\begin{tabular}{|c|c|c|c|c|c|c|}
\hline \multirow{2}{*}{$\begin{array}{c}\text { Sl. } \\
\text { No }\end{array}$} & \multirow{2}{*}{ Variables } & \multicolumn{2}{|c|}{ Cases } & \multicolumn{2}{c|}{ Controls } & \multirow{2}{*}{ P Value } \\
\cline { 2 - 6 } & & Mean & SD & Mean & SD & \\
\hline 1 & Sr. Ferritin(ng/ml) & 14.5 & 10.6 & 34.9 & 23.3 & 0.00 \\
\hline 2 & HB (gm\%) & 9.8 & 1.2 & 11.3 & 1.1 & 0.00 \\
\hline 3 & MCV (fl) & 76.0 & 8.5 & 79.5 & 7.5 & 0.02 \\
\hline 4 & MCH (pg) & 27.7 & 3.1 & 28.7 & 3.6 & 0.11 \\
\hline \multicolumn{2}{|r|}{ Table 1: Mean value of serum ferritin and blood indices among cases and controls } \\
\hline
\end{tabular}

The mean serum ferritin, Hemoglobin and Mean Corpuscular Volume were significantly lower in the febrile seizure group than with the reference group. Even though the Mean Corpuscular Hemoglobin is less among children with febrile seizures it did not achieve statistical significance (Table 1). 


\begin{tabular}{|c|c|c|c|c|c|c|c|}
\hline \multirow{2}{*}{$\begin{array}{l}\text { Sl. } \\
\text { No }\end{array}$} & \multicolumn{2}{|c|}{ Variables } & \multicolumn{2}{|c|}{ Cases } & \multirow{2}{*}{$\begin{array}{c}\text { Controls } \\
\mathbf{N}\end{array}$} & \multicolumn{2}{|c|}{ P Value } \\
\hline & & & $\mathbf{N}$ & $\%$ & & $\%$ & \\
\hline \multirow{2}{*}{1} & Serumferritin & $<10$ & 41 & 65.1 & 15 & 23.8 & \multirow{2}{*}{0.00} \\
\hline & $(\mathrm{Ng} / \mathrm{ml})$ & $>/-10$ & 22 & 34.9 & 48 & 76.2 & \\
\hline \multirow{2}{*}{2} & \multirow{2}{*}{$\begin{array}{c}\mathrm{HB} \\
(\mathrm{Gm} \%)\end{array}$} & $<11$ & 51 & 80.9 & 19 & 30.1 & \multirow{2}{*}{0.00} \\
\hline & & $>/-11$ & 12 & 19.1 & 44 & 69.9 & \\
\hline \multirow{2}{*}{3} & \multirow{2}{*}{$\begin{array}{c}\mathrm{MCV} \\
(\mathrm{Fl})\end{array}$} & $<70$ & 23 & 36.5 & 8 & 12.7 & \multirow{2}{*}{0.003} \\
\hline & & $>/-70$ & 40 & 63.5 & 55 & 87.3 & \\
\hline \multirow{2}{*}{4} & $\mathrm{MCH}$ & $<24$ & 10 & 15.9 & 9 & 14.3 & \multirow{2}{*}{1.00} \\
\hline & $(\mathrm{Pg})$ & $>/-24$ & 53 & 84.1 & 54 & 85.7 & \\
\hline \multicolumn{8}{|c|}{$\begin{array}{c}\text { Table 2: Proportion of children with low serum } \\
\text { ferritin/blood indices among cases and controls }\end{array}$} \\
\hline
\end{tabular}

Significant proportion of children with febrile seizures has low serum ferritin, Hemoglobin and Mean Corpuscular Volume than did the controls. However the proportion of children with low Mean Corpuscular Hemoglobin among those with febrile seizures and controls did not achieve statistical significance (Table 2).

\begin{tabular}{|c|c|c|c|c|c|}
\hline $\begin{array}{l}\text { Sl. } \\
\text { No }\end{array}$ & \multicolumn{2}{|l|}{ Variables } & Odds Ratio & $95 \% \mathrm{CI}$ & P Value \\
\hline \multirow{2}{*}{1} & \multirow{2}{*}{ Serumferritin $(\mathrm{ng} / \mathrm{ml})$} & $<10$ & 6.0 & $2.7,13.0$ & \multirow{2}{*}{0.00} \\
\hline & & $>/-10$ & 1.0 & Reference & \\
\hline \multirow{2}{*}{2} & \multirow{2}{*}{$\begin{array}{c}\mathrm{HB} \\
(\mathrm{gm} \%)\end{array}$} & $<11$ & 9.8 & $4.3,22.5$ & \multirow{2}{*}{0.00} \\
\hline & & $>/-11$ & 1.0 & Reference & \\
\hline \multirow{2}{*}{3} & \multirow{2}{*}{$\begin{array}{c}\text { MCV } \\
\text { (f1) }\end{array}$} & $<70$ & 4.0 & $1.6,9.7$ & \multirow{2}{*}{0.003} \\
\hline & & $>/-70$ & 1.0 & Reference & \\
\hline \multirow{2}{*}{4} & \multirow{2}{*}{$\begin{array}{l}\mathrm{MCH} \\
(\mathrm{pg})\end{array}$} & $<24$ & 1.1 & $0.4,3.0$ & \multirow{2}{*}{1.00} \\
\hline & & $>/-24$ & 1.0 & Reference & \\
\hline \multicolumn{6}{|c|}{$\begin{array}{l}\text { Table 3: Serum ferritin and blood indices among } \\
\text { cases and controls: Univariate analysis }\end{array}$} \\
\hline
\end{tabular}

